\title{
Chemical Analysis of Eucalyptus grandis Wood Manured with Biosolid on Two Valuation Methods
}

\author{
Ricardo Marques Barreiros ${ }^{1, ~ *, ~ F a ́ b i o ~ M i n o r u ~ Y a m a j i ², ~ T u f i c ~ M a d i ~ F i l h o ~}$ \\ ${ }^{1}$ Department of Industrial Engineering, State University of São Paulo, Itapeva-SP, Brazil \\ ${ }^{2}$ Department of Environmental Sciences, Federal University of São Carlos, Sorocaba-SP, Brazil \\ ${ }^{3}$ Energy and Nuclear Research Institute, University of São Paulo, São Paulo-SP, Brazil
}

Email address:

rmbarreiros@itapeva.unesp.br (R. M. Barreiros), fmyamaji@ufscar.br (F. M. Yamaji), tmfilho@ipen.br (T. M. Filho)

${ }^{*}$ Corresponding author

\section{To cite this article:}

Ricardo Marques Barreiros, Fábio Minoru Yamaji, Tufic Madi Filho. Chemical Analysis of Eucalyptus grandis Wood Manured with Biosolid on Two Valuation Methods. American Journal of Heterocyclic Chemistry. Vol. 3, No. 5, 2017, pp. 55-59. doi: 10.11648/j.ajhc.20170305.12

Received: October 9, 2017; Accepted: October 18, 2017; Published: November 10, 2017

\begin{abstract}
Neutron activation analysis followed by a gamma-ray spectroscopy and physico-chemical methods were used to conduct a thorough investigation of the elements transferred from sewage sludge (biosolid) into the wood of Eucalyptus grandis. Four different manure samples were analyzed: control without biosolid and samples with 10, 20 and $40 \mathrm{t} \mathrm{ha}^{-1}$ of biosolid. A significant increase of $\mathrm{Ca}$ was detected, but there was no change in $\mathrm{K}$ and a clear decline in Mn. The experiment showed that the application of biosolids is a good alternative as fertilizer, since it gives a destination to this residual product without compromising the wood with heavy metals, it can even make the cellulose pulp bleaching process less expensive, due to the decrease of the content of $\mathrm{Mn}$.
\end{abstract}

Keywords: Sewage Sludge, Gamma-Rays Spectroscopy, Thermal Neutron Activation, Heavy Metals, Cellulosic Pulp

\section{Introduction}

A current and significant global problem is the final destination of residues and terminal products. Sewage effluent is one such example. The quantity of effluent is increasing gradually due to the demand of society for better living conditions. The development of more advanced environmental policies, including the treatment of sewage effluent, is required from both the public and private sectors. After treatment, sewage effluent becomes solid and is called a biosolid.

Forest plantations, such as those of Eucalyptus sp., are a possible destination for treated sewage sludge. Biosolid can be used in forest plantations as fertilizer or as a soil conditioner [1]. However, the use of biosolid in cultivation systems should be followed by an investigation of the environmental impacts and of if the practice is economically feasible [2, 3, 4].

As organic fertilizers, biosolid can present some disadvantages in comparison with chemical fertilizers due to their composition: biosolid have an unbalanced concentration of nutrients (low concentration of potassium) and can include various pathogenic organisms or heavy metals. These aspects suggest that it is perhaps better to use biosolid only in non-edible cultivation systems; however, previous studies do not indicate any restriction concerning the application of treated effluent for food crops $[5,6,7]$.

In reference [8], was studied the effects of biosolid on the chemical properties of a Brazilian soil and plants (sweet corn, carrot, cauliflower and radish). The results showed that the levels of accumulation in both the soil and plants were within permissible limits, and the heavy metal concentrations observed were not likely to cause problems. In [9], was applied biosolid to two types of soil. The results indicated that sandy soil was more positively affected compared to clayey soil. Biosolid can be partially incorporated into soils, improving their structure, especially in sandy soils.

In [10], was treated biosolids from a municipal sewage scheme in Nelson, New Zealand has been applied to a nearby Pinus radiata forest plantation growing on a sandy, low-fertility soil since the mid-1990s. Indications from this 
study suggest that land application of biosolid can significantly increase the economic returns from a plantation forest on such sites.

Also in New Zealand, eleven native species tested benefited, in either growth or nutrient status, from biosolids addition to low-fertility soil. The addition of biosolid into degraded soil could improve and accelerate the growth and establishment of the eleven native plants tested [11].

The presence of detectable amounts of contaminants in treated sewage sludge (concentrations $\mu \mathrm{g} / \mathrm{kg}-\mathrm{mg} / \mathrm{kg}$ ) has led to concerns that land applications of biosolids may result in an accumulation of contaminants in the soil and their subsequent translocation through the food chain [12].

The use of biosolid in wood production has promise, but it is necessary to study the components that are transfered from the biosolid into the tree. The presence of some metals such as $\mathrm{Fe}, \mathrm{Cu}, \mathrm{Zn}, \mathrm{Mn}, \mathrm{Cd}$ and $\mathrm{Pb}$ in the pulpwood can affect the pulp-bleaching process, making it more expensive.

Research has progressed considerably about methods of chemical analysis of tissues, especially plant tissues. The procedures used to identify the highest range of elements and the techniques for determining their concentrations have become faster and more accurate. The use of extraction via the solubilization of chemical elements appears to be promising for chemical analysis. This methodology has small operational risk and produces wastes, that are easily neutralized, minimizing impacts to the environment [13]. Such methods are very common in the determination of macro-elements $(\mathrm{N}$, $\mathrm{P}, \mathrm{K}, \mathrm{Ca}, \mathrm{Mg}$ and $\mathrm{S}$ ) and in microelements (B, Fe, $\mathrm{Cu}, \mathrm{Zn}, \mathrm{Mn}$ and $\mathrm{Na}$ ) [14]. In [8, 9], was used chemical and physic-chemical techniques to analyze the effects of biosolids on the soil and plants in Brazil.

Radioactive methods are widely used in the context of physics, and are spreading to some interdisciplinary fields, including biology [15]. One of these methods is gamma-ray spectroscopy (GRS), which is used to measure the gamma ray emitted by radioactive nuclides that can be produced by exposing a piece of wood to neutrons. The neutrons penetrate the nuclei, exciting them, and then they decay to the ground state (lowest energy), emitting a detectable gamma ray. This technique has already been used in wood science, according to $[16,17]$, but without a careful description regarding the radioactive experimental procedure [18].

According to these same authors, the GRS is a very powerful method and currently its usage is not restricted to the physics context; the popularity of the method is increasing in many other disciplines.

Metals in the wood, such as iron, copper and manganese, may also be present in the pulp, damaging its bleaching, especially when it is made with peroxides, resulting in the peroxide decomposition and giving rise to intermediate radicals that can degrade cellulose $[19,20]$.

The aim of this work was to investigate the masses of transferred components from the biosolid into the tree by using a physic-chemical method (PCM) and gamma-ray spectroscopy (GRS).

\section{Materials and Method}

In this work, was used two methods to investigate the variation of 13 elements found in stem wood samples of Eucalyptus grandis W. Hill (Myrtaceae) with respect to the amount of biosolid added into the soil during the planting season. One method is based on neutron activation analysis followed by gamma-ray spectroscopy [18]. The other one is a physic-chemical method [21]. Four groups of Eucalyptus grandis were analyzed: a control without biosolid and treatments with 10,20 and $40 \mathrm{t} \mathrm{ha}^{-1}$ (dry weight basis) of biosolid. Using the GRS, the following elements were detected: $\mathrm{Br}, \mathrm{Mn}, \mathrm{Na}$ and $\mathrm{K}$. Using the PCM, the following elements were detected: $\mathrm{N}, \mathrm{P}, \mathrm{K}, \mathrm{Ca}, \mathrm{Mg}, \mathrm{S}, \mathrm{B}, \mathrm{Cu}, \mathrm{Fe}, \mathrm{Mn}$ and Zn.

Five-year-old trees were planted in a typical red-yellow latosol that was dystrophic (clay $=120 \mathrm{~g} \mathrm{~kg}^{-1}$ at $0-120 \mathrm{~cm}$ layer) and in a climate characterized as humid mesothermic (Cwa) according to the Köppen classification.

Figure 1 is a schematic of the randomized block design used in this experiment. The planted area was divided into four lines, A to D, and four columns, one to four. In each line, was applied one of four soil treatments to each "square" (A1, A2, A3 and A4): 1) Control - No mineral fertilization and no biosolid; 2) $10 \mathrm{t} \mathrm{ha}^{-1}$ of biosolid $+\mathrm{K}$; 3) $20 \mathrm{t} \mathrm{ha}^{-1}$ of biosolid + $\mathrm{K}$; 4) $40 \mathrm{t} \mathrm{ha}^{-1}$ of biosolid $+\mathrm{K}$. All treatments received $165 \mathrm{~kg}$ $\mathrm{ha}^{-1}$ of $\mathrm{K}_{2} \mathrm{O}$ to the biosolid mixture because it had a low concentration of $\mathrm{K}$. In [22], also was added $150 \mathrm{~kg} \mathrm{ha}^{-1}$ of $\mathrm{K}_{2} \mathrm{O}$ to biosolid because they detected the symptoms of $\mathrm{K}$ deficiency. In [23], was used 6.5 to $30 \mathrm{t} \mathrm{ha}^{-1}$ of biosolid plus synthetic fertilizer (N-P-K) for corn and forage.

Trees located near the limits were discarded to ensure that there was no interference between treatments. From a group of 100 trees planted in a space measuring $3 \mathrm{~m} \mathrm{x} 2 \mathrm{~m}$, was selected two trees based on the mean diameter at breast height (DBH).

Was used biosolid from Sewage Treatment Plant of Barueri-SP, Brazil, that was classified as Class B (Table 1). These biosolid contained about $300 \mathrm{~g} \mathrm{~kg}^{-1}$ of organic material, the ratio between carbon and nitrogen was 4.3 , the humidity was $60 \%$ and the $\mathrm{pH}$ was $12\left(\right.$ in $\left.\mathrm{H}_{2} \mathrm{O}\right)$.

Table 1. Mass (M) in grams of each element contained in $1 \mathrm{~kg}$ of biosolid from the Sewage Treatment Plant of Barueri-SP-Brazil, classified as Class B.

\begin{tabular}{|c|c|c|c|c|c|c|c|c|c|c|c|c|c|c|}
\hline & & & Elem & & & & & & & & & & & \\
\hline & $\mathrm{C}$ & $\mathbf{N}$ & $\mathbf{P}$ & $K$ & Ca & Mg & $\mathbf{N a}$ & $\mathbf{S}$ & $\mathrm{Fe}$ & $\mathrm{Cu}$ & $\mathrm{Zn}$ & Mn & Cd & $\mathbf{P b}$ \\
\hline$M(g)$ & 114.0 & 26.2 & 9.5 & 1.3 & 95.0 & 3.0 & 0.5 & 6.0 & 39.2 & 0.9 & 1.5 & 0.3 & 0.02 & 0.2 \\
\hline
\end{tabular}

Where: $\mathrm{M}=$ mass; $\mathrm{g}=$ grams; $\mathrm{C}=$ carbon; $\mathrm{N}=$ nitrogen; $\mathrm{P}=$ phosphorus $\mathrm{K}=$ potassium; $\mathrm{Ca}=$ calcium; $\mathrm{Mg}=$ magnesium; $\mathrm{Na}=$ sodium; $\mathrm{S}=$ sulfur; $\mathrm{Fe}=$ iron; $\mathrm{Cu}$ = copper; $\mathrm{Zn}=$ zinc; $\mathrm{Mn}=$ manganese $\mathrm{Cd}=$ cadmium; $\mathrm{Pb}=$ lead. 
Was produced samples from each tree using five disks (4 $\mathrm{cm}$ thickness) extracted at $0,25,50,75$ and $100 \%$ of the commercial height. The samples were analyzed with two distinct techniques (PCM and GRS).

For the PCM, proceeded as follows. The wood samples were cut in chips and put into an oven with a fan-forced air circulation at $65^{\circ} \mathrm{C}$ to dry until constant weight. These samples were then turned into sawdust in a Wiley-type mill equipped with 40 mesh sieves. The wood was digested using nitric and perchloric acid methods. The concentrations of $\mathrm{Ca}, \mathrm{Mg}, \mathrm{Cu}$, $\mathrm{Fe}, \mathrm{Mn}$ and $\mathrm{Zn}$ were determined by atomic absorption spectrophotometry. The quantity of $\mathrm{P}$ was determined by colorimetry, the amount of $\mathrm{S}$ by turbidimetry and the concentration of $\mathrm{K}$ using a flame photometer. The concentration of $\mathrm{N}$ was determined by titration after wood digestion in sulfuric acid. The concentration of B was determined using colorimetry after the incineration of the wood sample and extraction with chloridric acid. The concentration of all elements using the PCM was calculated based on dry weight.

The wood samples were irradiated with thermal neutrons in a reactor. The elements $\mathrm{K}, \mathrm{Na}, \mathrm{Mn}$ and $\mathrm{Br}$ were detected from the following nuclear reactions, respectively:

$$
\begin{aligned}
& { }^{41} \mathrm{~K}+\mathrm{n} \rightarrow{ }^{42} \mathrm{~K}+\gamma \\
& { }^{23} \mathrm{Na}+\mathrm{n} \rightarrow{ }^{24} \mathrm{Na}+\gamma \\
& { }^{55} \mathrm{Mn}+\mathrm{n} \rightarrow{ }^{56} \mathrm{Mn}+\gamma \\
& { }^{81} \mathrm{Br}+\mathrm{n} \rightarrow{ }^{82} \mathrm{Br}+\gamma
\end{aligned}
$$

Where " $n$ " represents a neutron and " $\gamma$ " is a gamma ray that was detected by a high-purity germanium detector. The detection/quantification of $\gamma$ 's allows the calculation of the quantity of each element in the left-hand-side of Equations (1) to (4). The abundance in nature of isotopes ${ }^{41} \mathrm{~K},{ }^{23} \mathrm{Na},{ }^{55} \mathrm{Mn}$, ${ }^{81} \mathrm{Br}$ is $6.73 \%, 100 \%, 100 \%$ and $49.31 \%$, respectively.

\section{Results and Discussion}

It was detected 13 elements with the two techniques. The mass (in grams) of each element in $1 \mathrm{~kg}$ of wood was plotted as a function of the biosolid used to fertilize the trees. Each element is indicated inside the Figures 1, 2 and 3.

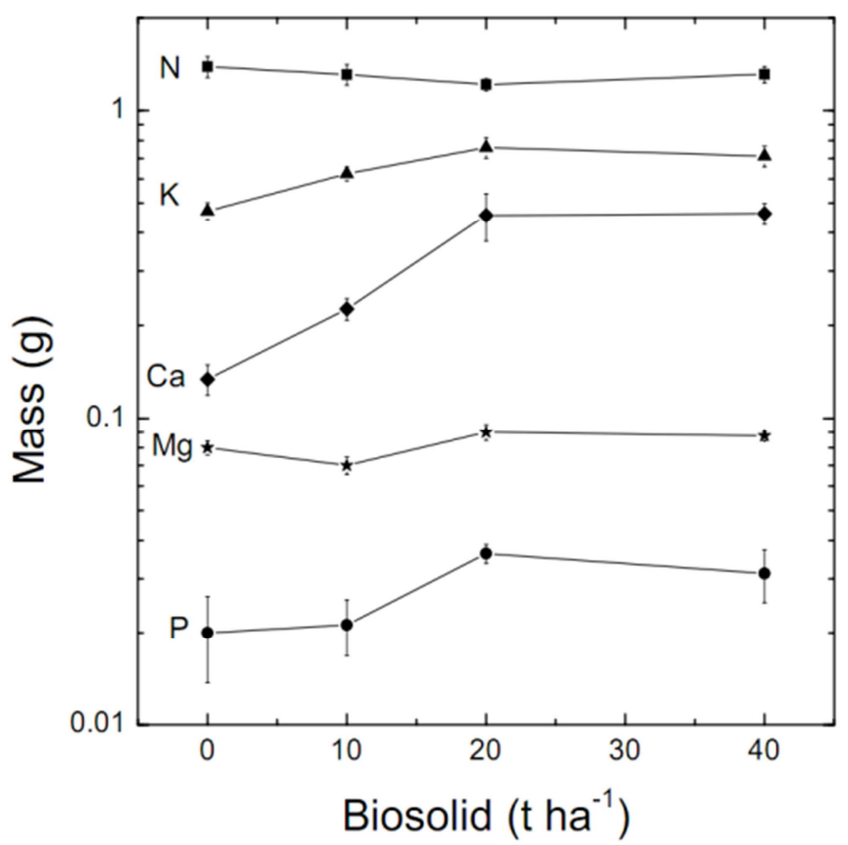

Figure 1. Mass of each element (in grams) indicated inside the Figure, in $1 \mathrm{~kg}$ of Eucalyptus grandis as a function of the biosolid ( $\left.t \mathrm{ha}^{-1}\right)$, used to manure the trees (detected using a PCM).

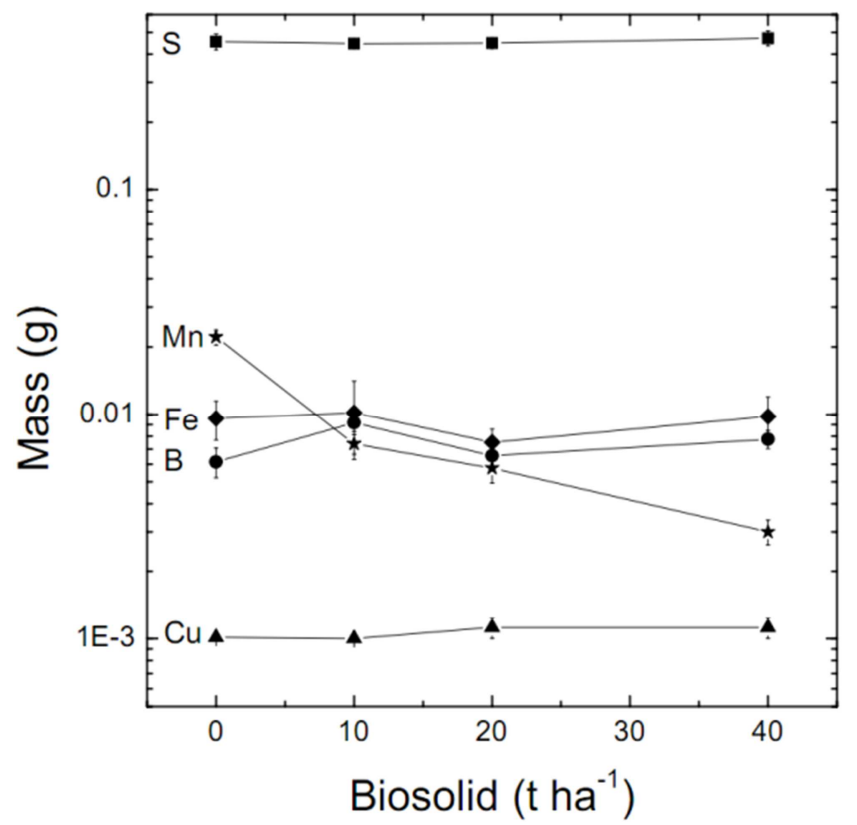

Figure 2. Mass of each element (in grams - mass $<0,1 \mathrm{~g}$ ) indicated inside the Figure, in $1 \mathrm{~kg}$ of Eucalyptus grandis as a function of the biosolid ( $\mathrm{t} \mathrm{ha} \mathrm{I}^{-1}$ ), used to manure the trees (detected using a PCM). 


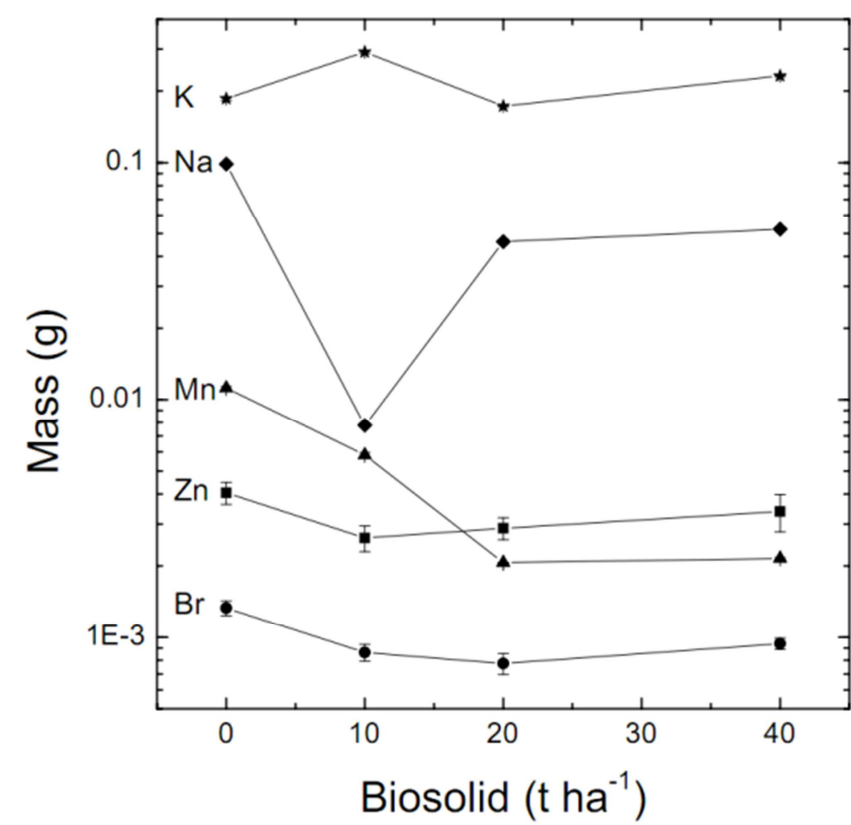

Figure 3. Mass of each element (in grams) indicated inside the Figure, in $1 \mathrm{~kg}$ of Eucalyptus grandis as a function of the biosolid ( $\left.t \mathrm{ha}^{-1}\right)$, used to manure the trees (detected by GRS).

Only the elements $\mathrm{K}, \mathrm{Na}, \mathrm{Mn}, \mathrm{Zn}$ and $\mathrm{Br}$ in Figure 4 were detected by GRS. The other elements, including Mn and $\mathrm{K}$, were detected using a PCM (Figures 2 and 3). In Figure1, it is possible to identify increases of $\mathrm{Ca}$ and $\mathrm{K}$, and in Figures 2 and 3 there is a decrease of Mn that can be seen. Considering the error bars, we can say that we have practically no difference in the concentration of other elements when the amount of biosolid increases.

It is worthwhile to mention that the masses of $\mathrm{Mn}$ determined by the two methods have the same magnitude. The discrepancy of $\mathrm{K}$ determined by the two methods can be analyzed considering the mass ratio of $\mathrm{K}$ and $\mathrm{N}$ in an ash sample of Tabebuia sp. that is about 118 [18]. One of the problems of biosolids is their low concentration of potassium. Biosolids are therefore expected to have a lower mass ratio between potassium and sodium than the one found in Tabebuia sp. The ratios of potassium from Figure 1 (determined by PCM) and sodium from Figure 3 (determined by GRS) are $4.772,81,16.425$ and 13.653 for the treatments of $0,10,20$ and $40 \mathrm{t}$ of biosolid per ha, respectively. If we consider the potassium from Figure 3 (GRS), the ratios were 2, 38,4 and 15 for treatments with $0,10,20$ and 40 t of biosolid per ha, respectively. Thus, the amount of potassium determined by GRS is more reasonable than that determined by PCM (even considering the addition of $\mathrm{K}_{2} \mathrm{O}$ to the biosolid). This can indicate a possible overestimation of the masses determined by the PCM. However, as the aim of this work was to compare the masses according to the biosolid used, i.e., the absolute values are not importants, this overestimation does not affect our final conclusions.

\section{Conclusion}

Using thermal neutron irradiation followed by GRS and
PCM methods, 13 elements were analyzed from $E$. grandis W. Hill (Myrtaceae) wood as a function of the biosolid used to manure the trees.

The use of biosolid does not add any heavy metals that could affect the pulp bleaching process or the use of the wood for other commercial purposes. Moreover, the addition of biosolid caused a decrease of $\mathrm{Mn}$, which can make the pulp bleaching process less expensive.

Others elements, such as: $\mathrm{N}, \mathrm{Mg}, \mathrm{S}, \mathrm{Fe}, \mathrm{Cu}, \mathrm{B}$ and $\mathrm{Br}$, did not have their contents modified by increases in the amount of biosolid applied, especially $\mathrm{Fe}$ and $\mathrm{Cu}$, which are undesirable in the bleaching of the pulp.

The results of this study are in accordance with $[8,9,10,11$, 12], in which the authors' conclusions suggest that the use of biosolid to manure trees can be an interesting alternative for the destination of this residue product.

\section{Acknowledgements}

The authors thank the college professor Gustavo Ventorim for a helpful discussion.

\section{References}

[1] T. F. Sampaio, I. A. Guerrini, X. L. Otero, F. M. Vazquez, J. C. Bogiani, F. C. Oliveira, J. L. Gava, M. A. Ciol, K. M. Littke and R. B. Harrison. The impact of biosolid application on soil and native plants in a degraded brazilian Atlantic Rainforest soil. Water, Air \& Soil Pollution, 227 (1): 1-9, 2016.

[2] G. N. Rocha, J. L. M. Gonçalves and I. M. Moura. Changes in soil fertility and growth of an Eucalyptus grandis plantation fertilized with biosolid. Rev. Bras. Ciências do Solo, 28 (3): 623-639, 2004.

[3] C. A. Andrade, C. Oliveira and C. C. Cerri. Organic matter quality and carbon and nitrogen stocks in an oxisol treated with biosolids and cultivated with Eucalyptus. Revista Brasileira de Ciências do Solo, 29 (5): 803-816, 2005.

[4] R. Chasse, S. Delbaen and M. Herbert. Development of quality criteria based on a toxicological characterization of fertilizing residuals. Journal. Environ. Eng. Science, (5):2 03-210, 2006.

[5] R. M. Barreiros. Changes in quality of Eucalyptus grandis caused by fertilization with sewage sludge. São Paulo University, 2005.

[6] F. Sonmez and M. A. Bozkurt. Lettuce grown on calcareous soils benefit from sewage sludge. Acta Agr. Scand., 56 (1): 17-24, 2006.

[7] N. C. Del Campo, I. L. Pepper and C. P. Gerba. Assessment of Salmonella typhimurium growth in Class A biosolids and soil/biosolid mixtures. Journal Resid. Sci. Technology, (4): 83-88, 2007.

[8] D. V. Pérez, S. Alcantara, C. C. Ribeiro, R. E. Pereira, G. C. Fontes, M. Wasserman, T. C. Venezuela, N. A. Meneguelli, J. R. Macedo, C. A. A. Barradas. Composted municipal waste effects on chemical properties of a Brazilian soil. Bioresource Technology, (98): 525-533, 2007. 
[9] E. I. Bertoncini, V. D’Orazio, N. Senesi and M. E. Mattiazzo. Effects of sewage sludge amendment on the properties of two Brazilian oxisols and their humic acids. Bioresource Technology, 99 (11): 4972-4979, 2008.

[10] M. O. Kimberley, H. Wang, P. J. Wilks, C. R. Fisher and G. N. Magesan. Economic analysis of growth response from a pine plantation forest applied with biosolids. Forest Ecology and Management, (189): 345-351, 2004.

[11] M. J. Gutiérrez-Ginés, B. H. Robinson, J. Esperschuetz, E. Madejón, J. Horswell and R. McLenaghen. Potential use of biosolids to reforest degraded areas with New Zealand native vegetation. Journal of Environmental Quality, 46 (4): 906-914, 2017.

[12] R. M. Clarke and E. Cummins. Evaluation of "classic" and emerging contaminants resulting from the application of biosolids to agricultural lands: a review. Hum. Ecol. Risk Assess, 21 (2): 492-513, 2015.

[13] C. Carneiro, C. B. Reissmann and R. Marques. Comparison of methods of chemical analysis of $\mathrm{K}, \mathrm{Ca}, \mathrm{MG}$, and $\mathrm{Al}$ in leaves of yerba mate (Ilex paraguariensis St. Hil.). Revista Cerne, 12 (2): 113-122, 2006.

[14] E. Malavolta. ABC of soil and leaves analysis: sampling, interpretation and fertilization suggestions. Piracicaba, CENA/USP, Ed. Agron. Seres Ltda. 1992.

[15] J. D. T. Arruda Neto, V. P. Likhachev, G. P. Nogueira, G. W. Araujo, S. P. Camargo, G. T. Cavalcante, A. C. Cestari, A. M. Craveiro, A. Deppman, J. W. Ferreira, F. Garcia, L. P. Geraldo, F. Guzmán, O. M. Helene, M. V. Manso, M. N. Martins, J. Mesa, M. F. Oliveira, G. Perez, O. Rodriguez, M. V. Tavares and V. R. Vanin. Transfer coefficient measurements of uranium to the organs of wistar rats as a function of the uranium content in the food. Applied Radiation and Isotopes, 54 (6): 947-956, 2001.
[16] A. M. Meyer and J. F. Siau. Neutron activation analysis of potassium in red pine wood from fertilized and unfertilized plots. Wood science, (8): 199-200, 1976.

[17] K. Unlu, P. I. Kuniholm, J. J. Chiment and D. K. Hauck. Neutron activation analysis of absolute-dated tree rings. J. Rad. Nucl. Chem., 264 (1): 21-27, 2005.

[18] M. T. Yamashita, F. Almeida Filho, R. M. Barreiros, F. Bringas, I. D. Goldman, T. Madi Filho, P. R. Pascholati and F. M. Yamaji. Determination of potassium and sodium in an ash sample by gamma-ray spectroscopy. Wood Sci. Technol. (40): 493-499, 2006.

[19] J. L. Colodette, J. L. Gomide and D. M. Carvalho. Composição química de materiais lignocelulósicos. Em: J. L. Colodette and F. J. B. Gomes. (eds) Branqueamento de polpa celulósica: da produção da polpa marrom ao produto acabado. Viçosa, Ed. UFV, 31-58, 2015.

[20] F. J. B. Gomes and E. F. Alves. Propriedades físicas. Em: J. L. Colodette and F. J. B. Gomes. Branqueamento de polpa celulósica: da produção da polpa marrom ao produto acabado. Viçosa, Ed. UFV, 721-734, 2015.

[21] E. Malavolta, G. C. Vitti and A. S. Oliveira. Nutritional assessment of plants: principles and applications. Piracicaba, Ed. Potafos. 1997.

[22] J. R. Crush, U. Sarathchandra and A. Donnison. Effect of plant growth on dehydration rates and microbial populations in sewage biosolids. Bioresource Technology, 97(18):2447-2452, 2006.

[23] P. R. Warman and W. C. Termeer. Evaluation of sewage sludge, septic waste and sludge compost applications to corn and forage: $\mathrm{Ca}, \mathrm{Mg}, \mathrm{S}, \mathrm{Fe}, \mathrm{Mn}, \mathrm{Cu}, \mathrm{Zn}$ and $\mathrm{B}$ content of crops and soils. Bioresource Technology, 96 (9): 1029-1038, 2005. 